\title{
Yeast one-hybrid system
}

新美 輝幸、塩見 邦博、片桐 伸悦（名古屋大院・生命農） 清宮麻希子（バーゼル大・バイオセンター）

niimi@agr.nagoya-u.ac.jp

分子生物学の発展により、さまざまな生命 現象が分子の言葉で語られるようになってき た。その中で中心的役割を果たす分子として、 数多くの転写因子が明らかにされている。転 写因子の多くは、生物全般に広く存在し、系 統関係の遠い生物においても共通した㗢きを もつことが示されている。例えば、Pax-6は 眼の形態形成において重要な役割を果たすこ とが、構造の異なる眼をもつ生物においても 示されている1)。Pax-6のDNA結合領域のアミ ノ酸配列は多くの生物間でよく保存されてい る。しかし、実際にはヒトの眼とショウジョ ウバエの複眼を比較すると、その構造が異な ることは一目瞭然である。では、このような 眼の構造の違いはどのようにしてもたらされ たのか。このような問題を明らかにするため には、Pax-6の標的遺伝子の同定が必要であ る。しかし、ほとんどの転写因子の場合どの 作用をin vivoに近い環境で解析するのに有効 な方法として、yeast one-hybrid systemが用い られている。本稿では、one-hybrid systemを紹 介し、実際どのような解析に用いられている かについて解説するとともに、この方法の有 効性と問題点についても述べたい。

\section{原 理}

Two-hybrid systemがタンパク質間の相互作 用を検索するのに対し、one-hybrid systemは、 タンパク質とDNAの相互作用を検索する方法 である。以下の応用の項目で述べるように、 様々な方法が開発されているが、ここでは

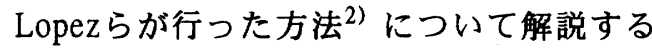
(図1)。

DNA結合タンパク質のcDNAとその標的配 列のクローニングには、大腸菌之酵母の両方 で增殖することのできるシャトルベクターを

遺伝子をコントロ ールし、その生命 現象の発現を調節 しているかについ ては明らかにされ ていない場合が多 い。一方、ある面 白い現象の分子マ 一カーとなる遺伝 子を単離した場合 には、この遺伝子 の発現を制御する 上位の遺伝子の同 定が課題となる。 以上のような転写 因子とDNAの相互

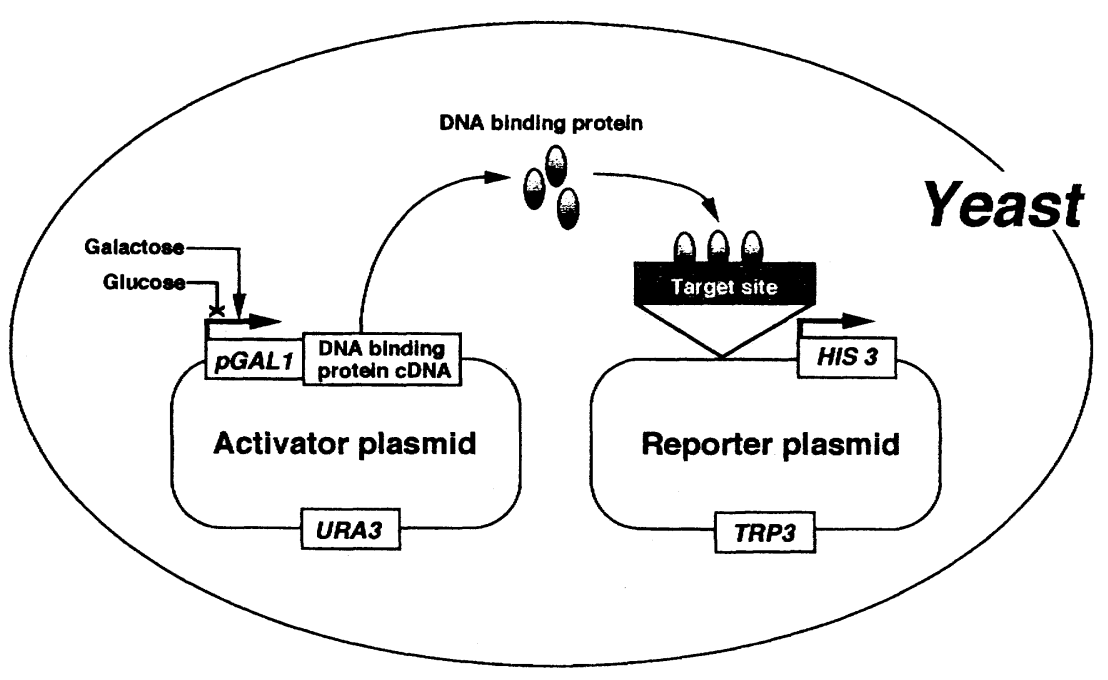

図1 One-hybrid systemの原理 
用いる。Activator plasmidはGAL1プロモー夕 一を含んでおり、この下流にDNA結合タンパ ク質のcDNAを挿入する。GAL1プロモーター は、グルコースにより抑制され、ガラクトー スにより誘導される。従って、培地にガラク トースが含まれる場合のみに目的のタンパク 質合成を誘導することができる。また、この ベクターには、ウラシル欠損培地での生育を 可能にする選択マーカーとしてURA3が挿入 されている。

Reporter plasmidには、標的配列をHIS3の上 流に挿入する。このベクターには、トリプト ファン欠損培地での生育を可能にする選択マ 一カーとしてTRP3が挿入されている。

上記の 2 種のプラスミドをもつ酵母(ウラシ ル、トリプトファンおよびヒスチ ジン要求株、以下単に醅母と記し ても同様の要求株のことを示す) においては、ガラクトースによっ てDNA結合タンパク質が誘導さ れ、このタンパク質が標的となる DNAの配列に結合することによっ てHIS3が発現し、ヒスチジンが欠 損した選択培地上で醳母が初めて 生育可能となる。つまり、トラン スフォームした醉母が選択培地上 で生育できるかどうかによって、 DNA結合タンパク質が標的配列に 結合するかどうかを判定すること ができるのである。また、HIS3の 代わりにlacZをレポーターに用い ればコロニーの色による判別と活 性の定量化が可能である。

\section{方 法}

あるDNA結合タンパク質がその 標的と予想されるDNAの配列に結 合するかどうかを検定する手順を 図2に示した。Activator plasmidへ のDNA結合タンパク質cDNAのク ローニングとreporter plasmidへの 標的配列のクローニングは、生育
が早く取り扱いの便利な大腸菌を用いて行 う。これらの両べクターを酵母にコトランス フォーメーションし、ウラシルとトリプトフ アンを欠くグルコースの選択培地にまくと、 両ベクターを含む睛母のみが生育しコロニー を形成する。レプリカプレート上での結果の 判定を容易にするため、ここで増えたコロニ 一のいくつかを爪楊枝の柄でとり、同じ選択 培地上に図2のように塗り広げる。酵母が均 一に十分增殖したら、これをマスタープレー トに用い、種々の選択培地にレプリカする。 ヒスチジン、ウラシルおよびトリプトファン を欠くガラクトースの選択培地上で増殖する ことのできる醳母は、DNA結合タンパク質が その標的と予想されるDNAの配列に結合した

\section{Cotransformation \\ $\left(\begin{array}{c}\text { Activator plasmid } \\ + \\ \text { Reporter plasmid }\end{array}\right)$}

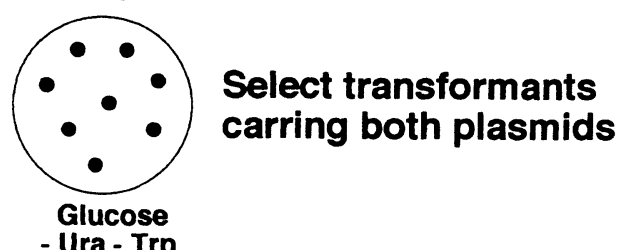

Pick up and streak

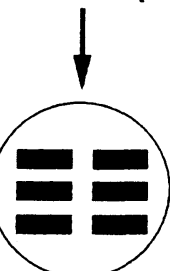

Amplify the colonies

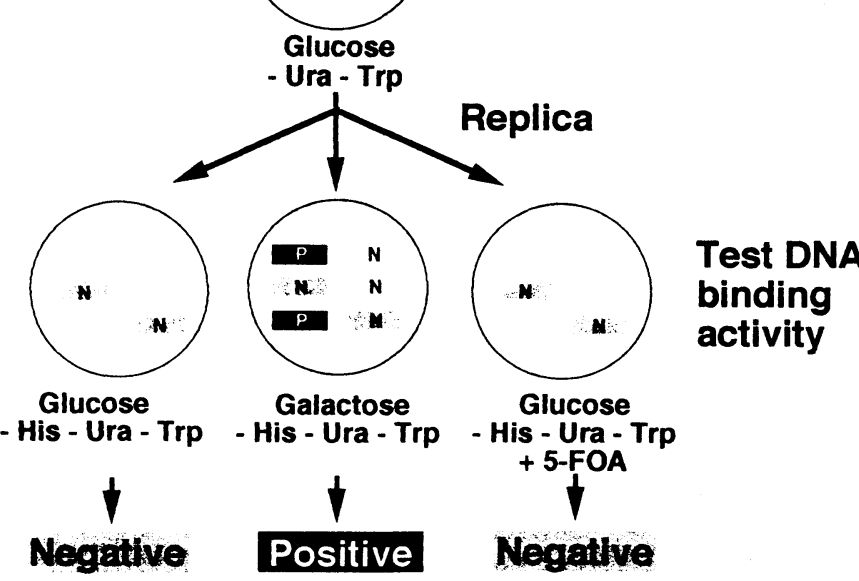

図2 One-hybrid systemの実験の手順 


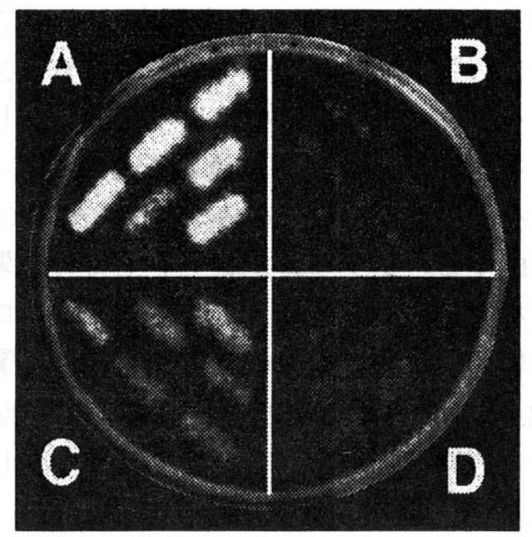

図3 One-hybrid systemの実験例 ショウジョウバエのPax-6相同遺伝子である eyelessの標的遺伝子の検索を試みた。 eyeless cDNAをactivator plasmidに㨉入し、 標的と予想された遭伝子の断片 (A, B, C, D) をreporter plasmidに挿入した。この2種のプ ラスミドをコトランスフォーメーションし、 この醉母がヒスチジン、ウラシルおよひト リプトファンを欠くガラクトースの選択培 地上で生育するかどうかを検定した。その 結果、Eyelessは標的遭伝子の断片AとCに結 合することが示された。

ものと推論される(図3)。この結果を確かめ るため、ヒスチジン、ウラシルおよびトリプ トファンを欠くグルコースの選択培地上で増 殖するかどうかを試す。Activator-plasmidの DNA結合タンパク質の発現はグルコースによ り抑制されるので、ここで増殖したものは醉 母の内在性タンパク質がこの配列に結合する ことによりHIS3の発現を引き起こしたと考え られる。また、ヒスチジン、ウラシルおよび トリプトファンを欠き、5-fluoro-oretic acid(5FOA）を添加したガラクトースの選択培地上 において增殖した場合も擬陽性である。5FOAはURA3により代謝されると、醅母の生 育を阻害する毒素に変化するため、URA3を もつactivator plasmidとは関係なく増殖したと 考えられるからである。

\section{応用例}

表1に示したように、これまでに様々な種 類の転写因子が酵母の中で働くことが示され
ている。しかし、すべてのDNA結合タンパク 質が酵母で転写活性化因子として働くとは限 らない。この場合には、VP16やGa14の転写活 性化領域とのfusionタンパク質を作ることに よって酵母で転写活性化因子として作用する ような工夫が必要である。

以下に述べるAのように、個々のタンパク 質とその標的配列との相互作用を解析する場 合、酵母のトランスフォーメーション法は効 率よりも簡便さを重視する。一方、B、Cの ようなスクリーニングの場合には、最も効率 の良いトランスフォーメーション法を用いる3)。 また、レポーターにHIS3のような欠損選択マ 一カーを用いれば、一枚のプレート上でより 多くのコロニーのスクリーニングが可能とな る。

ここでは、これまでに行われた応用例を紹 介し、その具体的な例は表1にまとめた。

\section{A. DNA結合タンパク質の構造と機能の解析}

まず最初に、大腸菌のLexAが酵母で転写 因子として作用することが1984年に示された4)。 それ以後、この性質を利用し、LexAのDNA 結合領域と他の生物で発見された転写因子と のfusion夕ンパク質を醅母で発現させ、 $\beta$-ガ ラクトシダーゼの活性を指標に転写因子の機 能ドメインの検索が行われた ${ }^{5 \sim 10) 。 こ れ に よ ~}$ り、基本的な転写機構は多くの生物種間で保 存されていることが示された。

転写因子のDNA結合領域のアミノ酸に突然 変異を導入し、どのアミノ酸がDNAの結合に 関与するかの解析も行われた ${ }^{11)}$ 。

また、ステロイドホルモンを培地に添加す ることにより、核内レセプターであるヒトの エストロゲンレセプターが䤉母においても、 ホルモンの作用によってDNAの結合性を獲得 することが示された ${ }^{12)}$ 。

2種のDNA結合タンパク質を、それぞれ異 なる欠損選択マーカーををもつ activator plasmidにインサートしたものと標的配列がイ ンサートされたreporter plasmidとの3種のプラ スミドを同時に酵母にトランスフォームする 
表 1 Yeast one-hybrid systemの応用例

\begin{tabular}{|c|c|c|}
\hline モチーフ & 枟写因子 & Ref. \\
\hline \multirow[t]{3}{*}{ b-Zip } & GCN4 & 6 \\
\hline & jun & 7 \\
\hline & fos & 8 \\
\hline \multirow[t]{4}{*}{ Zn-finger } & estrogen receptor & 12 \\
\hline & glucocorticoid receptor & 18 \\
\hline & viral erbA & 19 \\
\hline & cubitus interruptus & 20 \\
\hline \multirow[t]{5}{*}{ HD } & fushi tarazu & 21 \\
\hline & Ultrabithorax & 10,22 \\
\hline & abdominal-A & 10 \\
\hline & Deformed & 22 \\
\hline & Hoxa-7 & 11 \\
\hline \multirow[t]{2}{*}{ HLH } & achaete-scute + daughterless $*$ & 13 \\
\hline & $\mathrm{c}-\mathrm{myc}+\max *$ & 14 \\
\hline
\end{tabular}

*:ヘテロタイマーとして解析された転军因子

\section{B : 電的面列の㭘索}

\begin{tabular}{ccc}
\hline 模索に用いられた伝写因子 & モチーフ & Ref. \\
\hline NGFI-B & Zn-finger & 23 \\
Hoxa-5 & HD & 24 \\
Hoxb-6 & HD & 24 \\
Hoxc-8 & HD & 24 \\
Ultrabithorax & HD & 2 \\
p53 & その他 & 15 \\
\hline
\end{tabular}

\section{C：DNA㰴合タンパク貿の检索}

\begin{tabular}{lc}
\hline 模索に用いれらたシスエレメント & Ref. \\
\hline cis-element from olfactory specific genes & 25 \\
yeast origin of DNA replication & 17 \\
metal response element & 16 \\
E-box (HI,H recognition element) & 26 \\
\hline
\end{tabular}

ことにより、へテロダイマーが形成されては じめてDNA結合能を獲得する転写因子の解析 が行われた $1^{3,14) 。}$

一方、reporter plasmidの標的配列中の塩基 に置換を導入し、転写因子の標的配列に対す る結合親和性を $\beta$-ガラクトシダーゼの活性 を測定することにより解析した例もある11)。

\section{B. DNA結合タンパク兵の標的遺伝子のスク リーニング}

既知のDNA 結合タンパク質のcDNAを activator plasmidに㨂入し、reporter plasmidには、 その生物のゲノムDNAを $500 \mathrm{bp}$ 程の大きさの 断片にしたものを㨂入して、ゲノム中の標的 配列の検索をする。さらに明らかとなった標
的配列をもとに、cDNAをクロー ニングすれば標的遺伝子の同定も 可能となる2)。

\section{C. シスエレメントに結合する DNA結合タンパク質遺伝子の} スクリーニング

ある面白い現象の分子マーカー となる遺伝子を単離した場合、こ の遺伝子の調節領域をreporter plasmidにクローニングする。そし て、その遺伝子が発現する組織の cDNAライブラリーを作製して activator plasmidに挿入してスクリ 一ニングすれば、この遺伝子の調 節領域に結合するDNA結合タンパ ク質のクローニングが可能とな る。この場合、DNA結合タンパク 質が転写活性化因子であるとは限 らないので、Ga14の転写活性化領 域とのfusionタンパク質を発現さ せる方が好ましい。

\section{長所と短所}

この方法の長所は、検索すべき DNA結合タンパク質のcDNAまた はシスエレメントをもっていれ ば、これらをone-hybrid system用のベクターに クローニングすることにより、応用の項で示 したような解析が非常に簡便に行うことがで きることである。例えば、筆者らの経験では、 方法の項で述べた一連の操作に必要な日数は 以下の通りである。コトランスフォーメーシ ヨン(半日)、そのコロニーの生育(2日)、マ スタープレート上での酵母の生育 (1日)、レ プリカプレート上での醳母の生育(3日)、以 上合計約1週間である。

また、酵母という制約はあるものの、タン パク質とDNAの相互作用がin vivoに近い環境 で検出できることも大きな特幑である。

短所は、標的配列の検索に用いる塩基は、 最大 $2 \mathrm{kbp}$ 程度であり ${ }^{2)}$ 、より短い方が好まし 
いことである。従って、応用例Cの場合、ス クリーニングに用いるDNAの大きさをある程 度絞りこんでおくことが望ましい。また、検 索に用いる塩基配列が酵母に内在するタンパ ク簤によって認識されると、 activator plasmid に挿入されたDNA結合タンパク質の標的配列 への結合性は検出不可能となる。

また、いかにして擬陽性を判定するかも重 要な問題である。そのため、方法の項で述べ たように、種々の選択培地での酵母の生育を 試す必要がある。この場合、何もインサート されていないactivator plasmidと目的の標的配 列がインサートされたreporter plasmidをコト ランスフォーメーションし、この酥母がヒス チジン、ウラシルおよびトリプトファンを欠 くガラクトースの選択培地上で生育しないこ とを確認することも有効である15)。また、レ ポーターには、lacZとHIS3の2種類を用い、 両方とも陽性になるものを選択することが、 スクリーニングの際の真の陽性の判定には有 効である ${ }^{16)}$ 。応用例Cの場合、シスエレメン トの解析が進んでいれば、このシスエレメン トに変異を導入した配列への結合性も陽性か どうかの判定基準に用いることができる ${ }^{17) 。 ~}$

\section{おわりに}

これまで生命の基本的な原理はモデルとな る生物中心にして明らかにされてきた。そし て生命の基本的な原理に関わる分子は、多く の生物で共通することがわかってきた。しか し、地球上には100万を超える生物種が存在 し、それぞれの生物は種保存のための優れた 機能や戦略をもつ。このような多様性のうえ に生態系が成り立っている。生物が獲得して きた多様性の解明のためには、モデルとなる 生物の研究だけでなく、これまであまり扱わ れることのなかった生物の研究も必要にな る。転写因子のように多くの生物においてそ の共通性が認められている遺伝子は、PCR法 により相同遺伝子のクローニングは容易に行 うことができる。しかし、転写因子によって 調節される下位の遺伝子は必ずしも多くの生
物に共通するとは限らない。この様な遺伝子 の単離にはホモロジーを利用したクローニン グ法は使えない。また、微量しか存在しない ようなタンパク質を精製し単離することは容 易ではない。しかし、醉母を利用したonehybrid systemはDNA結合タンパク質や標的遺 伝子の単離を比較的簡単に行うことができ る。従って、one-hybrid systemは、現在twohybrid system程ポピュラーではないが、今後 その重要性がさらに増してくるものと思われ る。

本稿の執筆にあたり、多くの貴重な御助言 を下さった柳沼利信博士に感謝します。

\section{参考文献}

1 ) Callaers, P. et. al. Ann. Rev. Neurosci. 20, in press, 1997

2) Mastick, G.S. et. al. Genetics 139, 349-363, 1995

3 ) Kaiser, C. et. al. ed. Methods in Yeast Genetics, Cold Spring Harbor Laboratory Press, 1994

4 ) Brent, R. \& Ptashne, M. Nature 312, 612-615, 1984

5 ) Brent, R. \& Ptashne, M. Cell 43, 729-736, 1985

6) Hope, I. A. \& Struhl, K. Cell 46, 885-894, 1986

7) Struhl, K. Cell 50, 841-846, 1987

8 ) Lech, K. et. al. Cell 52, 179-184, 1988

9 ) Struhl, K. Nature 332, 649-650, 1988

10) Samson, M.-L. et. al. Cell 57, 1045-1052, 1989

11) Gross, M. K. \& Gruss, P. Mol. Cell. Biol.14, 238-254, 1994

12) Metzger, D. et. al. Nature 334, 31-36, 1988

13) Cabrera, C.V. \& Alonso, M.C. EMBO J. 10, 2965-2973, 1991

14) Amati, B. et. al. Nature $359,423-426,1992$

15) Tokino, T. et. al. Hum. Mol. Genet. 3, 15371542, 1994

16) Inouye, C. et. al. DNA Cell Biol. 13, 731-742, 1994 
17) Li. J.J. \& Herskowitz, I. Science 262, 18701874, 1993

18) Schena, M. \& Yamamoto, K. R. Science 241 , 965-967, 1988

19) Privalsky, M. L. et. al. Cell 63, 1277-1286, 1990

20) Alexander, C. et. al. Genes Dev. 10, 20032013, 1996

21) Fitzpatrick, V.D. \& Ingles, C. J. Nature 337, 666-668, 1989
22) Ekker, S. C. et. al. EMBO J. 11, 4059-4072, 1992

23) Wilson, T. E. et. al. Science 252, 1296-1300, 1991

24) Friedman-Einat, M. et. al. J. Exp. Zool. 274, 145-156, 1996

25) Wang, M. M. \& Reed, R. R. Nature 364,121 126, 1993

26) Mak, K.-L. et. al. DNA Cell Biol. 15, 1-8, 1996

\section{日本比較内分泌学会 編 / 全7巻 ホルモンの分子生物学}

\section{1 ホルモンの分子生物学 序説 4 甲状腺ホルモン}

加藤幸雄・浦野明央 編 220 頁 $\cdot 3600$ 円

2 成長ホルモン・プロラクチン ファミリー

針谷敏夫・川内浩司 編 200 頁 $\cdot 3600$ 円

\section{3 生殖とホルモン}

小林牧人・加藤順三 編

(近刊)

\section{5 ストレスとホルモン}

田中滋康・中山和久編

(近刊)

6 発生亡成長因子・ホルモン 服部眞彰・上野直人 編 170 頁・ 3400 円

7 ホメオスタシス
竹井祥郎・広瀬茂久編

(近刊)

\section{学会出版センター}

T113 東京都文京区本郷6-2-10 Tel.03-3814-2001 Fax. 03-3814-2002 